\title{
A study on important factors influencing customers' impulsive buying behavior: A case study of Shahrvand food chain
}

\author{
Naser Azad*, Bahram Azizi, Hamed Asgari and Hamid Bagheri
}

Department of Management, Islamic Azad University, South Tehran Branch, Tehran, Iran

\begin{tabular}{|c|c|}
\hline CHRON I C LE & A B S T R A T T \\
\hline $\begin{array}{l}\text { Article history: } \\
\text { Received January 12, } 2013 \\
\text { Received in revised format } \\
9 \text { April } 2013 \\
\text { Accepted } 10 \text { April } 2013 \\
\text { Available online } \\
\text { April } 102013 \\
\text { Keywords: } \\
\text { Factor analysis } \\
\text { Food chain } \\
\text { Critical factors }\end{array}$ & $\begin{array}{l}\text { Customer purchasing behavior plays an essential role on marketing planning in today's } \\
\text { competitive environment. Impulsive buying behavior is one of the most important components } \\
\text { of purchasing behavior. In this paper, we use factor analysis to extract important factors } \\
\text { influencing impulsive buying behavior. The proposed study of this paper designs a } \\
\text { questionnaire including } 35 \text { questions and through basic investigation, the questions are reduced } \\
\text { to } 21 \text { ones. The questionnaire is distributed among } 200 \text { regular customers and } 149 \\
\text { questionnaires have been collected. Cronbach alpha has been calculated as } 0.804 \text {, which is well } \\
\text { above the minimum desirable level of } 0.7 \text {. The survey is conducted among regular customers } \\
\text { who normally make purchases from Shahrvand food chains in city of Tehran, Iran. The results } \\
\text { of factor analysis reveals four major factors including intelligence pricing strategy, } \\
\text { involvement, promotion margin and consumer behavior. The proposed study of this paper } \\
\text { considers "intelligence pricing strategy" for the first time as an important factor in consumer's } \\
\text { purchasing behavior. }\end{array}$ \\
\hline
\end{tabular}

(C) 2013 Growing Science Ltd. All rights reserved.

\section{Introduction}

Consumer is believed to be the most important component of selling a product and we always need to understand consumers' intension on immediate purchase (Kalla \& Arora, 2011; Azad et al., 2013). When consumer changes his/her behavior, product elasticity will reduce and price has to decrease, accordingly (Rook, 1987; Beatty \& Ferrell, 1998; Azad \& Hashemi, 2012). Therefore, offering a product with appropriate characteristics helps people become competitive on the market. During the past few years, there have been extensive studies on measuring the impact of important factors on marketing planning. Azad and Hashemi (2013), for instance, presented an empirical investigation to find important factors influencing customer relationship management and extracted five important factors including economic factors, communication skills, organizational resources, service capabilities and flexible market.

\footnotetext{
*Corresponding author.

E-mail addresses: dr.naserazad@yahoo.com (N. Azad) 
1416

Mihić and Kursan (2010) used a market segmentation approach to make an assessment on the situational factors and impulsive buying behavior. Coley and Burgess (2003) studied gender differences in cognitive and affective impulse buying. Jones et al. (2003) investigated the productspecific nature of impulse buying tendency. According to Mattila and Wirtz (2001), retailers have long understood the relative importance of store environment in enhancing the shopping experience.

Harmancioglu et al. (2009) examined consumers' cognitive processes and motivations for making impulse purchases of new products. Lee and Kacen (2008) investigated the cultural influences on consumer satisfaction with impulse and planned purchase decisions. Hausman (2000) performed a multi-method investigation of consumer motivations in impulse buying behavior.

Silvera et al. (2008) studied the impulse buying effects of social influence, and subjective wellbeing. Franken et al. (2008) tried to understand whether impulsivity was associated with behavioral decision-making deficits or not. Babin and Attaway (2000) investigated the atmospheric effects as a tool for creating value and gaining share of customer. Peck and Childers (2006) performed an investigation on individual and environmental influences on impulse purchasing. Verplanken et al. (2005) studied the role of impulsive buying in unhealthy eating.

Azad (2012) surveyed important factors, influencing customers to purchase more from one of wellknown food market operating in capital city of Iran named Shahrvand. The survey studied the impacts of six factors including customer's perception, persuasive factors, brand, customers' expectations, product's characteristics and special features of store on attracting more customers. The results indicated that customers' perception was the most important item, which includes eight components. Years of experience was the most important item in their survey followed by impact of color and working hours. Diversity of services was another factor, which played the most important role followed by quality of services. Next, fidelity and brand were other most important factors and the name of store and risk are in lower degree of importance.

Azad and Hamdavipour (2012) performed another study on effects of packaging characteristics on consumer's purchasing confidence. Their results indicated that a good and label with detailed and precise information on product could significantly influence customer's confidence while other visible information did not have much impact on customer's confidence. Azad and Masoumi (2012) investigated the impact of packaging on product competition.

In this paper, we study important factors influencing on immediate purchasing plan among regular customers of a food chain in city of Tehran, Iran called Shahrvand. The organization of this paper first presents details of the proposed study in section 2, while the results of the survey are presented in section 3 and concluding remarks are given in the last to summarize the contribution of this paper.

\section{The proposed study}

The proposed study of this paper tries to find important factors influencing on immediate purchasing plan among regular customers of a food chain in city of Tehran, Iran called Shahrvand. The study has designed a questionnaire and has distributed among 200 customers and managed to collect 149 filled ones. The proposed study of this paper uses factor analysis to extract important factors.

Cronbach alpha has been calculated as 0.804 , which is well above the minimum desirable level of 0.7. Kaiser-Meyer-Olkin Measure of Sampling Adequacy has been calculated as 0.758 and Bartlett's test of Sphericity approximation Chi-Square has also been calculated as 709.202 , which validate the overall results. 


\section{The results}

The proposed study of this paper has detected four major factors using factor analysis and in this section, we present details of our findings.

\subsection{The first factor: Intelligence pricing strategy}

The first factor, "intelligence pricing" strategy includes five components and Table 1 summarizes details of our findings on this factor.

\section{Table 1}

The summary of factors associated with intelligence pricing strategy

\begin{tabular}{lcccc}
\hline \multicolumn{1}{c}{ Option } & Factor weight & Eigenvalue & \% ofvariance & Accumulated \\
\hline Specifying value for products' components & .692 & 4.456 & 21.217 & 21.217 \\
Exciting pricing & .667 & & & \\
Competitive pricing & .647 & & & \\
Having choice & .534 & & & \\
Pricing popular products & .644 & & & \\
\hline Cronbach alph $=0.693$ & & & &
\end{tabular}

Cronbach alph $=0.693$

As we can observe from the results of Table 1, "Specifying value for products' components" is the most important component of this factor followed by "exciting pricing" and "competitive pricing". According to our survey, consumer preferences or "having choice" is the least important factor followed by "pricing popular products".

\subsection{The second factor: Involvement}

Consumer perception and involvement is the second important factor influencing consumer immediate purchasing behavior and it includes five components summarized in Table 2 as follows,

Table 2

The summary of factors associated with involvement

\begin{tabular}{lcccc}
\hline Option & Factor weight & Eigenvalue & \% ofvariance & Accumulated \\
\hline Interest in purchase & .795 & 1.843 & 8.744 & 29.991 \\
Enjoy from purchasing & .685 & & & \\
Purchase importance & .624 & & & \\
Desirability of purchase & .640 & & & \\
Purchasing products fitting consumer behavior & .414 & & & \\
\hline Cronbach alph $=0.640$ & & &
\end{tabular}

Based on the results of Table 2, we can conclude "interest in purchase" is accounted number one priority followed by "enjoy from purchasing" and "desirability of purchase". In our survey, "Purchasing products fitting consumer behavior" is the last priority followed by "purchase importance".

\subsection{The third factor: Consumer advantage margin}

Consumer advantage margin is the third important factor impacting consumer immediate purchasing behavior which includes five factors summarized in Table 3 . Based on the results of Table 3, we understand "Saving" is the number one priority followed by "price discount" and "non-cash advantage". In addition, "fair pricing" is the last priority followed by "low level of consumer information". 
Table 3

The summary of factors associated with consumer advantage margin

\begin{tabular}{lcccc}
\hline Option & Factor weight & Eigenvalue & \% ofvariance & Accumulated \\
\hline Saving & .737 & 1.662 & 7.915 & 37.906 \\
Price discount & .689 & & & \\
Non-cash advantage & .658 & & & \\
Fair pricing & .336 & & & \\
Low level of consumer information & .456 & & & \\
\hline Cronbach alph $=0.640$ & & & &
\end{tabular}

\subsection{The fourth factor: Consumer behavior attribute}

Consumer behavior attribute is the last factor, which influences consumer immediate purchasing behavior and it includes four factors summarized in Table 4 as follows,

\section{Table 4}

The summary of factors associated with consumer behavior attribute

\begin{tabular}{lcccc}
\hline Option & Factor weight & Eigenvalue & \% ofvariance & Accumulated \\
\hline Consumer capability on measuring product quality & .772 & 1.533 & 7.301 & 45.207 \\
Personal believes & .688 & & & \\
Consumer precision on purchasing occasion & .547 & & & \\
Having diversified attitude on purchasing & .383 & & & \\
\hline Cronbach alph $=0.626$ & & &
\end{tabular}

Based on the results of Table 4, we understand "Consumer capability on measuring product quality" is the number one priority followed by "Personal believes". In addition, "Having diversified attitude on purchasing" maintains the lowest priority followed by "Consumer precision on purchasing occasion".

\section{Discussion and conclusion}

One of the most important factors in marketing planning is to detect essential factors influencing immediate purchasing behavior. The empirical investigation of this survey has detected four factors including "intelligence pricing strategy", "involvement", "promotion margin" and "consumer behavior". The results of this survey have concluded that "intelligence pricing strategy" is one of the most important factors, which has been considered as a new contribution in this study. In this strategy, "Specifying value for products' components" is the most important component of this factor followed by "exciting pricing" and "competitive pricing".

According to our survey, consumer preferences or "having choice" is the least important factor followed by "pricing popular products". The second factor has been involvement with five subcomponent and "interest in purchase" considered as number one priority followed by "enjoy from purchasing" and "desirability of purchase".

In our survey, "Purchasing products fitting consumer behavior" is the last priority followed by "purchase importance". The third factor on the survey was associated with consumer affordability and in our survey, "Saving" has been the number one priority followed by "price discount" and "noncash advantage". In addition, "fair pricing" has been the last priority followed by "low level of consumer information".

Finally, consumer behavior attribute was the last factor, which influences consumer immediate purchasing behavior and it includes four factors and while "Consumer capability on measuring product quality" was the number one priority followed by "Personal believes", "Having diversified 
attitude on purchasing" maintained the lowest priority followed by "Consumer precision on purchasing occasion".

\section{Acknowledgment}

The authors would like to thank anonymous referees for constructive comments on earlier version of this paper.

\section{References}

Azad, N., Hamdavipour, L. (2012). A study on effects of packaging characteristics on consumer's purchasing confidence. Management Science Letters, 2(1), 397-402.

Azad, N. (2012). Investigating important factors influencing purchasing from chains. Management Science Letters, 2(3), 805-810.

Azad, N., Hashemi, S. (2012). A study on important factors influencing customer relationship management: A case study of Mobile service provider. Management Science Letters, 2(4), 11611164.

Azad, N., Masoumi, M. (2012). The impact of packaging on product competition. Management Science Letters, 2(8), 2789-2794.

Azad, N., \& Hashemi, S. (2013). A study on important factors influencing customer relationship management: A case study of Mobile service provider. Management Science Letters, 3, 11611166.

Azad, N., Rostamnia, Y., \& Tazari, J. (2013). A study on important factors influencing innovation on computer hardware equipment: An empirical investigation using structural equation modeling. Management Science Letters, 3(4), 1291-1296.

Babin, B. J., \& Attaway, J. S. (2000). Atmospheric affect as a tool for creating value and gaining share of customer. Journal of Business Research, 49(2), 91-99.

Beatty, S. E., \& Ferrell, E. M. (1998). Impulse buying: modeling its precursors. Journal of Retailing, 74(2), 169-191.

Coley, A., \& Burgess, B. (2003). Gender differences in cognitive and affective impulse buying. Journal of Fashion Marketing and Management, 7(3), 282-295.

Franken, I. H., van Strien, J. W., Nijs, I., \& Muris, P. (2008). Impulsivity is associated with behavioral decision-making deficits. Psychiatry Research,158(2), 155.

Harmancioglu, N., Finney, R. Z., \& Joseph, M. (2009). Impulse purchases of new products: an empirical analysis. Journal of Product and Brand Management, 18(1), 27-37.

Hausman, A. (2000). A multi-method investigation of consumer motivations in impulse buying behavior. Journal of consumer marketing, 17(5), 403-426.

Jones, M. A., Reynolds, K. E., Weun, S., \& Beatty, S. E. (2003). The product-specific nature of impulse buying tendency. Journal of Business Research, 56(7), 505-511.

Kalla, S. M., \& Arora, A. P. (2011). Impulse buying: A literature review. Global Business Review, 12(1), 145-157.

Lee, J. A., \& Kacen, J. J. (2008). Cultural influences on consumer satisfaction with impulse and planned purchase decisions. Journal of Business Research,61(3), 265-272.

Mattila, A. S., \& Wirtz, J. (2001). Congruency of scent and music as a driver of in-store evaluations and behavior. Journal of Retailing, 77(2), 273-289.

Mihić, M., \& Kursan, I. (2010). Assessing the situational factors and impulsive buying behavior: Market segmentation approach. Management: Journal of Contemporary Management Issues, 15(2), 47-66.

Peck, J., \& Childers, T. L. (2006). If I touch it I have to have it: Individual and environmental influences on impulse purchasing. Journal of business research,59(6), 765-769.

Rook, D. W. (1987). The buying impulse. Journal of consumer research, 189-199. 
Silvera, D. H., Lavack, A. M., \& Kropp, F. (2008). Impulse buying: The role of affect, social influence, and subjective wellbeing. Journal of Consumer Marketing, 25(1), 23-33.

Verplanken, B., Herabadi, A. G., Perry, J. A., \& Silvera, D. H. (2005). Consumer style and health: The role of impulsive buying in unhealthy eating. Psychology \& Health, 20(4), 429-441. 